\title{
MUSICAL EXPRESSION: LESSONS FROM THE EIGHTEENTH CENTURY?
}

BETTINA VARWIG

\begin{abstract}
This article outlines a number of potential contributions that a consideration of early eighteenth-century conceptions of musical expressivity might make to certain present-day philosophical and psychological accounts of musical emotions and their expression. Taking as its central case study a recent performance by Christian Gerhaher in Peter Sellars' 2014 staging of Bach's Passion according to St John, the article calls for closer attention to both the historical specifics of music's expressive capacities and the corporeal dimension of performance (past and present). It argues that a more sustained engagement with these domains can productively complicate some fundamental assumptions that underpin current approaches to musical expression.
\end{abstract}

'The general system of the sciences and the arts is a sort of labyrinth, a tortuous road which the intellect enters without quite knowing what direction to take.' Jean Le Rond d'Alembert ${ }^{1}$

\section{CONTAINER OPTIMISM}

'There is no real mystery here', writes Patrik Juslin in his recent magisterial monograph Musical Emotions Explained. Music is expressive, of course, because 'musical sounds are

\footnotetext{
${ }^{1}$ Jean Le Rond d'Alembert, Preliminary Discourse to the Encyclopaedia of Diderot, trans.
} Richard N. Schwab, revised ed. (Chicago: University of Chicago Press, 1995), 46. 
created by human beings - usually with an expressive intention of some kind'. ' Juslin's optimism would not seem misplaced if transposed back three hundred or so years to the early eighteenth century. In that best of all possible bygone worlds, enlightenment came in the form of orderly categories and was often only a page turn away. A topic such as musical expression found itself as easily subject to taxonomic regulation as Carl Linnaeus' molluscs and arachnids. In order to find out about music's expressive capabilities, one might have reached, for instance, for Johann Mattheson's Vollkommener Capellmeister (1739), which offers a nowadays notorious catalogue of current musical genres and their expressive properties. ${ }^{3}$ Under the broad heading of 'Instrumental-Sachen', the minuet, with its three subspecies of 'for singing', 'for playing' and 'for dancing', is described as having 'no other affect than moderate gaiety' (224); the March, subdivided into two classes of 'serious' and 'comic', is 'heroic and fearless, but in no way wild or running' (226); the gavotte, with its 'skipping' rather than 'running' nature, communicates 'exultant joy' (225), the angloise 'stubbornness' (229) and the courante 'sweet hope' (230). The gigue is split into four subcategories, each with its own expressive markers: the 'regular' gigue displays an ardent and volatile zeal; the slow loure has a proud and pompous demeanour; the canarie is avid and swift, but with a certain naivety; and the Italian giga, used in fiddling rather than dancing,

\footnotetext{
2 Patrik N. Juslin, Musical Emotions Explained (Oxford: Oxford University Press, 2019), 73.

${ }^{3}$ Johann Mattheson, Der Vollkommene Capellmeister (Hamburg: Herold, 1739), Part II,
} Chapter 13. 
exhibits an 'extreme swiftness or fleetingness; though for the most part in a flowing rather than a frenzied manner; somewhat like the smooth arrow-swift flow of a stream. ${ }^{4}$

Mattheson intended his volume primarily as a manual for practitioners, promising that 'the presentation of the order and constitution of these genres should work to the benefit of a composer and his clear understanding of his art, as much as inexperience in this respect will cause confusion and impediment'. ${ }^{5}$ An aspiring musician, then, faced with the task of setting a text that, for instance, talked about a swift kind of action, like hurrying or fleeing, could make an informed decision to set such words in the style of a giga. This was apparently the association Johann Sebastian Bach made when confronted with the following words:

Eilt, ihr angefochtnen Seelen,

Geht aus euren Marterhöhlen,

Eilt - Wohin? - nach Golgatha!

Nehmet an des Glaubens Flügel,

Flieht - Wohin? - zum Kreuzeshügel,
Hurry, you besieged souls, leave your dens of torment, hurry - where? - to Golgotha! Embrace faith's wings; flee - where? - to the hill of the cross,

\footnotetext{
4 ‘ $̈$ usserste Schelligkeit oder Flüchtigkeit; doch mehrentheils auf eine fliessende und keine ungestüme Art: etwa wie der glattfortschiessende Strom-Pfeil eines Bachs', Mattheson, Capellmeister, 227-228. All translations are mine unless otherwise noted.

5 'Weil nun die Anzeige der Ordnung und Einrichtung solcher Gattungen eben so viel zum Vortheil eines Componisten und zum deutlichen Begriff seiner Wissenschafft beitragen muß, als die Unverfahrenheit in diesem Stücke Verwirrung und Hinderniß mit sich bringet', Mattheson, Capellmeister, 210-211.
} 
The text is derived from Barthold Heinrich Brockes' famous Passion libretto of 1712, quoted here in the adapted version as it appears in Bach's Passion according to St John of 1724. The aria occurs in Part II at the moment when Jesus has been delivered by Pilate to be crucified and is made to carry his cross to the site of his execution. It is a didactic text in dialogue form, replete with the customary poetic imagery, and instructing Lutheran believers where to run to - literally, to Golgotha, to witness the crucifixion of Jesus, and metaphorically, to Christ, to find their salvation. Bach's well-known setting, which pits an exhortatory solo bass against the disconcerted voices of the chorus, makes effective use of the conventional markers of the Italian gigue style, principally a fast triple metre and chains of running semiquavers (Figure 1). ${ }^{7}$ The opening gesture may be said to portray the beleaguered souls flying up towards the 'Kreuzeshügel'; in the following bars, in line with Sébastien de Brossard's definition of the gigue in his 1703 dictionary, Bach incorporates the kinds of leaps and syncopations that 'make the tune cheerful and, so to speak, jumping'. 8

$<<$ PLACE FIGURE 1 NEAR HERE $>>$

\footnotetext{
${ }^{6}$ Translation in Michael Marissen, Bach's Oratorios: The Parallel German-English Texts (New York: Oxford University Press, 2008), 119.

${ }^{7}$ See also Meredith Little and Natalie Jenne, Dance and the Music of J. S. Bach (Bloomington: Indiana University Press, 1991).

8 'Un air ordinairement pour less Instrumens, Presque toûjours en triple qui est plein de Notes pointées \& sincopées qui en rendent le chant gay, \& pour ainsi dire sautillant', Sébastien de Brossard, Dictionaire de Musique (Paris: Ballard, 1703), no page.
} 
On first glance, then, some of the piece's features would appear to satisfy the encyclopaedists well enough, neatly slotting into and thereby affirming the validity of their categories. Yet there is, on reflection, very little that seems 'cheerful' about either Brockes' text or Bach's setting. Watching Christian Gerhaher perform the piece in Peter Sellars' acclaimed 2014 staging of the Passion according to St John (with the Berlin Philharmonic Orchestra conducted by Simon Rattle), one would be hard pressed to find things flowing along smoothly. This, if anything, is a frenzied affair: the frequent semiquaver rests, shifting phrase groupings and contrapuntal cross-rhythms unsettle the dance's light-footed lilt; the interpolations from the chorus of lost souls defy the rules of rational dialogue, breaking in erratically with their repeated, overwrought questioning. As for Gerhaher, whatever one might make of the staged action unfolding around him, every fibre of his singing being seems suffused by a sense of panicked urgency, of dread and horror about what is about to take place, creating a forcefield of expression whose palpable charge wreaks havoc with contemporary standards of textual representation and affective propriety. The scene is expressive, for sure, but in a way that must appear almost incomprehensible in an orderly Matthesonian universe. ${ }^{9}$

${ }^{9}$ Johann Sebastian Bach, St. John Passion, DVD recording, directed by Peter Sellars, Berliner Philharmoniker Recordings BPHR140031, 2014. An excerpt of this performance can be viewed here: $<$ https://www.youtube.com/watch?v=w7cyHotTtcc $>$, accessed 17 June 2019. The full performance is available on the Berlin Philharmonic Digital Concert Hall website (by subscription): $<$ https://www.digitalconcerthall.com $>$. For a critical look at Sellars' recent Passion stagings, see Bettina Varwig, 'Beware the Lamb: Staging Bach's Passions', twentieth-century music 11/2 (2014), 245-274. 
My discerning readers may object here that, in terms of genre classifications, Bach's piece is not primarily a gigue, but an aria that merely borrows some elements of gigue style. (They may also object that the almost deranged effect just described is due to Gerhaher's and Rattle's particular (mis)reading of Bach's music; more on that below.) Mattheson himself accommodated the possibility of such genre crossover by including a supplementary category of 'Arietten a tempo di Giga zum Singen'. More generally, he pointed out that his definitions 'are not so much geared towards a complete understanding of just the dances, but towards the discovery of the riches contained therein, which can be fruitfully employed for a host of other seemingly more important things; especially in fine vocal pieces and the expression of affections of all kinds'. ${ }^{10}$ It was, of course, the great asset of the eighteenth-century aria that it could impersonate virtually any expressive stance that an underlying dramatic situation may require, and use any appropriate stylistic devices at hand to do so. Accordingly, Mattheson defined the genre of the aria in non-specific terms as a piece expressing a 'große Gemüthsbewegung' (great emotion, or motion of the soul). ${ }^{11}$ Something kinetic of this sort indeed seems to be occurring in 'Eilt, ihr angefochtnen Seelen'. But who or what is generating this motion, and of what kind is it?

The question of where to locate musical expression - by which, for the purpose of this essay, I refer broadly to the capacity of music to convey an emotional state (whether

10 'Alle diese neue Anmerckungen haben ihre Absicht nicht sowol ins besondere auf den völligen Begriff der blossen Tänze, als auf die Entdeckung des darin steckenden Reichthums und dessen gescheute Anwendung, bey einer Menge andrer und wichtiger-scheinenden Dinge: absonderlich bey feinen Singsachen und Ausdrückung der Leidenschafften allerhand Art.' Mattheson, Capellmeister, 228.

${ }^{11}$ Mattheson, Capellmeister, 212. 
perceived or actually felt) to its listeners - has exercised many wise thinkers for centuries, and I do not presume here to provide even the beginnings of a comprehensive answer in the vein of, say, Peter Kivy's classic account The Corded Shell, or Juslin's volume cited above. ${ }^{12}$ I do propose, however, that productive insights may be gained from a mode of enquiry attuned both to historical detail and to the visceral dimension of performance, two aspects which can fruitfully complicate the convenient construct of 'the music' that has underpinned various recent philosophical as well as psychological approaches to the issue. As Juslin notes, 'historical changes in expression are mostly beyond the scope of a psychological analysis', and, elsewhere, 'musicians are conspicuously absent from academic discussions about expression.' ${ }^{13}$ Specifically, my reflections here aim to probe the ways in which particular (performed) musical realities are wont to undermine the theoretical frameworks intended to encapsulate them (whether eighteenth-century or present-day). Bach's music, we may recall, was frequently considered 'unnatural' in his own time, overstretching the accepted formal and expressive properties of musical language: ${ }^{14}$ his repetitions were too extensive, his

${ }^{12}$ Peter Kivy, The Corded Shell: Reflections on Musical Expression (Princeton: Princeton University Press, 1980). This is not the place for a comprehensive review of multiple competing views concerning music and/as expression; my working definition is intended to be neither exhaustive nor exclusive. For a useful summary, see Andrew Kania, 'The Philosophy of Music', in The Stanford Encyclopedia of Philosophy, ed. Edward N. Zalta, https://plato.stanford.edu/entries/music/, accessed 17 June 2019.

13 Juslin, Musical Emotions Explained, 115.

${ }^{14}$ Johann Adolf Scheibe, Der Critische Musikus, second edition (Leipzig: Breitkopf, 1745; repr. Hildesheim: Olms, 1970), 46. 
inventions too turgid, his counterpoint too artificial. ${ }^{15}$ In hindsight, this friction tends to reflect negatively on the theorists rather than on Bach; surely Mattheson's categories are the problem, not the composer's creative impulses, since trying to compartmentalize musical expression into sets of easily classifiable stylistic markers is clearly a fraught undertaking. But if this is a first (albeit negative) lesson one might take from early eighteenth-century thought on expression - that is, that such categorization appears inadequate for capturing most musical particulars - then it may also give us pause about certain modern-day approaches to musical expressivity.

Whether or not one agrees with the Cartesian proposition that there are six (or, following more recent research, anywhere between two and fifteen) basic emotions that characterize the human condition, the attempt to understand musical expressivity by asking listeners to select the relevant option from among these categories can, in certain cases, end up looking startlingly similar to a Matthesonian taxonomy. ${ }^{16}$ Juslin offers just such a taxonomy in convenient table format: 'Sadness' in music is characterized by slow tempo, minor mode, dissonance, a low sound level and so on; 'angry' music is also dissonant and in a minor mode, but fast and loud; 'happy' music is fast with small tempo variability, in a major mode, with simple and consonant harmony and a medium-high sound level; and so

${ }^{15}$ On turgid invention and artificial counterpoint see Scheibe, Der Critische Musikus, 46-47; on repetitiveness, see Johann Mattheson, Critica Musica, vol. 2 (Hamburg, 1725), 368.

${ }^{16}$ For a useful, if slightly dated, summary of these different models, see Andrew Ortony and Terence J. Turner, 'What's basic about basic emotions?', Psychological Review 97/3 (1990), 315-331. See also Jesse J. Printz, Gut Reactions: A Perceptual Theory of Emotion (Oxford: Oxford University Press, 2004), 86-88. 
on. ${ }^{17}$ The concomitant simplification of the musical materials employed in some studies four short monophonic melodies in a foundational 1996 experiment by Alf Gabrielsson, 'to facilitate recordings and measurement'; 14 individual chords, to be rated on a 9-item emotion scale, in a 2016 study - can seem to reinforce these reductive tendencies. ${ }^{18}$ When Juslin cautions that 'if longer excerpts are used, the expression might change across the excerpts, leading to inconsistent responses', one may wonder whether perhaps such bothersome inconsistencies are exactly what characterizes live musical experiences. ${ }^{19}$ As Alexandra Lamont and Tuomas Eerola pointed out a few years ago, 'the search for ecological validity clearly remains a central concern' in the empirical study of music and emotion. ${ }^{20}$ And although researchers over the past decades have striven to refine their terminologies and expand their methodological toolkits, for example through a situational approach that focuses on the interaction between music, listener and listening occasion, the resulting analyses still tend to re-inscribe a basic happy-sad(-nostalgic) configuration. ${ }^{21}$ Most of these studies are

${ }^{17}$ Juslin, Musical Emotions Explained, 126.

${ }^{18}$ Alf Gabrielsson, 'Emotional Expression in Music Performance: Between the Performer's Intention and the Listener's Experience', Psychology of Music 24/1 (1996), 72; Imre Lahdelma and Tuomas Eerola, 'Single Chords Convey Distinct Emotional Qualities to Both Naïve and Expert Listeners', Psychology of Music 44/1 (2016), 37-54.

${ }^{19}$ Juslin, Musical Emotions Explained, 70.

${ }^{20}$ Alexandra Lamont and Tuomas Eerola, 'Music and Emotion: Themes and Development', Musicae Scientiae 15/2 (2011), 143.

${ }^{21}$ Patrik N. Juslin, Simon Liljeström and others, 'Emotional Reactions to Music in a Nationally Representative Sample of Swedish Adults: Prevalence and Causal Influences', Musicae Scientiae 15/2 (2011), 174-207. For a more in-depth review of recent approaches, 
accompanied by judicious disclaimers about their preliminary status due to the complexity of the subject matter, or by the caveat that emotional responses are only 'probabilistically associated' with musical cues. ${ }^{22}$ But even if the spectrum is expanded to a more refined catalogue of, say, 38 possible emotions (in a 2003 study led by Erik Lindström), the grounding assumption persists of a more or less direct chain of causalities involving the encoding and decoding of affective messages by composers, performers and finally listeners. ${ }^{23}$ Models such as the one laid out by Juslin (Figure 2) seem to rely on a curiously mechanistic conception of expressive communication (with 'communication accuracy' considered a marker of success) that Mattheson would easily have subscribed to as well.

\section{$<<$ PLACE FIGURE 2 NEAR HERE $>>$}

This fundamental trust in the ability of a system of signification to encompass and explicate musical expressivity - or human emotions more generally - warrants scrutiny in light of the historically and culturally situated nature of any supposedly standard emotion labels. As Jesse Prinz has suggested, if there are any basic emotions, humans are unable to articulate those, and as soon as they do give them names (or visual shapes in emoticons),

see Tuomas Eerola and Jonna Vuoskoski, 'A Review of Music and Emotion Studies: Approaches, Emotion Models and Stimuli', Music Perception 30/3 (2013), 307-340.

${ }^{22}$ Lena Quinto, William Forde Thompson and Alan Taylor, 'The Contributions of Compositional Structure and Performance Expression to the Communication of Emotion in Music', Psychology of Music 42/4 (2014), 1.

${ }^{23}$ Erik Lindström and others, "“Expressivity Comes From Within Your Soul”: A Questionnaire Study of Music Students' Perspectives on Musical Expressivity', Research Studies in Music Education 20/1 (2003), 23-47. 
these are mediated by culturally determined patterns of thought and communication. ${ }^{24}$ More specifically, Roger Scruton reminds us that 'the language of aesthetic description is (to use a metaphor) shot through with metaphor. Almost every term deployed in describing the aesthetic character of something ... is transferred from some other context. This is true too of the term "expression". 25 The words one might reach for in recounting experiences of musicking, then, necessarily stand in an oblique relation to their felt reality (that is, the 'felt emotion' domain which in Juslin's model tellingly fades into a less distinct grey area). This is obviously the case in Mattheson's analogy of rushing water, but also in his other descriptors of the gigue, such as 'Flüchtigkeit', whose field of associations in eighteenth-century German ranged from flying and fleeing to the transience of matter in the process of chemical evaporation. ${ }^{26}$ Not only do these multiple associations begin to shift when the term is translated into an English near-equivalent like 'fleetingness'; but as soon as that quality is actualized in a piece of music, its particular shades and nuances - determined by what Benedetto Croce would have called the artwork's unique 'intuition' - become impossible to capture in a generalized typology. ${ }^{27}$ No doubt such typologies allow for a kind of 'useful

${ }^{24}$ Jesse Prinz, 'Which Emotions Are Basic?', in Emotion, Evolution and Rationality, ed. Dylan Evans and Pierre Cruse (Oxford: Oxford University Press, 2004), 69.

${ }^{25}$ Roger Scruton, Aesthetics of Music (Oxford: Clarendon, 1997), 153. See also Lynn Fainsilber and Andrew Ortony, 'Metaphorical Uses of Language in the Expression of Emotions', Metaphor and Symbolic Activity 2/4 (1987), 239-250.

${ }^{26}$ See, for instance, Johann Heinrich Zedler's definitions of 'flüchtig' in his Grosses vollständiges Universal-Lexicon aller Wissenschaften und Künste volume 9 (Halle: Zedler, $1735), 1345$.

${ }^{27}$ See Scruton, Aesthetics of Music, 143. 
prejudice' that arguably is vital for successful social interaction. ${ }^{28}$ But Mattheson's efforts to distil the expressive essence of each musical genre run up, on the one hand, against the limitations of language as a means of conveying matters of feeling, and, on the other, against the persistent tendency of individual musical utterances to bypass or spill out of the verbal containers provided for them.

\section{II. 'FEELING-IN': EXPRESSIVE BODIES}

How, then, might we go about pinpointing - or at least approaching - musical expressivity outside the taxonomic certainties inherited from Enlightenment thinking? Lest we simply throw up our hands and fall silent in the face of music's expressive capabilities, I would suggest that there is indeed something salvageable here. For one, my portrayal so far has done less than full justice to the diversity of early eighteenth-century philosophical discourse generally and music-theoretical writings in particular. Other contemporary commentators frequently articulated different or sceptical views about ongoing efforts to subject all aspects of music to classificatory control: Johann David Heinichen, for instance, critiqued the attempt to pin down the expressive qualities of different keys, and instead urged attention to the particular compositional invention at work in a given piece. ${ }^{29}$ Heinichen would probably have enjoyed pointing out the discrepancies between Mattheson's rather bland characterization of G minor as 'combining a certain seriousness with a lively charm' and the striking effect of

\footnotetext{
${ }^{28}$ Naomi Cumming, 'The Subjectivities of "Erbarme Dich"”, Music Analysis 16/1 (1997), 23.

${ }^{29}$ Johann David Heinichen, Der General-Bass in der Composition (Dresden: Author, 1728), $83-86$.
} 
'Eilt, ihr angefochtnen Seelen', notated in that key. ${ }^{30}$ Moreover, even though many of Mattheson's categories are undoubtedly inadequate, his observations highlight certain aspects of (musical) expressivity that arguably deserve more sustained attention. As Martin Clayton and Laura Leante among others have discussed, most of our basic metaphors about music relate to 'embodied image schemas', outlining patterns or trajectories of physical movement. ${ }^{31}$ This is true, too, of many of Mattheson's descriptive terms; as somatic metaphors, they draw attention to the fundamentally embodied nature of expression itself. My opening discussion of 'Eilt, ihr angefochtnen Seelen' was purposely grounded in such matters of embodiment, specifically the bodies of the singers and players (re)creating the piece in the act of performance there and then.

How these bodies relate to the musical sounds they produce is of crucial importance, I would say, in tackling the question of where and how musical expression might be thought to arise. If much of the philosophical debate over the past decades has assumed to be examining 'the music' apart from the vicissitudes of individual performances and performers, such an approach tends to rest on deep-seated assumptions about how it - the music - is meant to go. This shines through, for instance, in Jenefer Robinson's commentary on Henry Purcell's motet 'Hear my prayer', which she finds 'most notable for the way in which it slowly increases in volume and intensity until the end (usually the final bar is sung somewhat more

${ }^{30}$ Johann Mattheson, Das Neu-Eröffnete Orchestre (Hamburg: Schiller, 1713), 237. To be fair, Mattheson himself also voiced some scepticism about this method; see 232.

${ }^{31}$ Martin Clayton and Laura Leante, 'Embodiment in Music Performance', in Experience and Meaning in Music Performance, ed. Martin Clayton, Byron Dueck and Laura Leante (New York: Oxford University Press, 2013), 194. See also Michael Spitzer, Metaphor and Musical Thought (Chicago: University of Chicago Press, 2004), especially 93-100. 
softly)' ${ }^{32}$ Robinson's appraisal of the work's emotional effects on herself is evidently based on a specific (if widely shared) performance tradition that imputes a particular expressive contour and intent. With respect to Bach, one encounters a similar unspoken conviction that, unlike some of his contemporaries, we have now come to understand how this music should sound and feel. It may seem uncontroversial, for instance, to claim, with Jerrold Levinson, that the F minor Prelude from Book 2 of the Well-Tempered Clavier, BWV881, expresses a 'chaste and mildly elegiac wistfulness', expertly projected in Daniel Barenboim's 2005 recording of the piece (on the modern piano). ${ }^{33}$ In Levinson's account, this expressive quality is determined by the work's structural features, including its harmonic trajectory, the sighing character of the opening motive, and its 'dominant rhythm of hesitancy and reserve' ${ }^{34}$ In the absence of any tempo or articulation marks in surviving eighteenth-century copies of the piece, such as that by Johann Philipp Kirnberger (Figure 3), Levinson's reading strikes me as entirely plausible (even if it seems unlikely that the lost autograph was filled with slurs and legato markings). What remains unaddressed, however, is a key point which, to my mind, Gerhaher's rendering of Bach's aria makes blatantly clear: that any such perceived expressiveness is necessarily embodied, or instantiated through a set of human bodily actions.

$<<$ PLACE FIGURE 3 NEAR HERE $>>$

32 Jenefer Robinson, Deeper than Reason: Emotion and its Role in Literature, Music, and Art (Oxford: Clarendon, 2005), 412.

${ }^{33}$ Johann Sebastian Bach, The Well-Tempered Clavier, Parts I \& II, CD recording, Daniel Barenboim, Warner Classics B000I5Y7MY, 2006.

${ }^{34}$ Jerrold Levinson, Music, Art and Metaphysics: Essays in Philosophical Aesthetics (New York: Oxford University Press, 2011), 150-151. 
This is not merely a matter of different performance styles applied to an invariable musical structure. Rather, as Nicholas Cook's recent yet already classic plea for a performance-oriented musicology surmises, 'it is only once you think of music as performance that you can start to make sense of scores' ${ }^{35}$ It is certainly the case that, upon listening to Cornelius Hauptmann's recording of the same Bach aria (with the English Baroque Soloists, directed by John Eliot Gardiner), one would find its affective qualities much more contained; more, perhaps, like Mattheson's smooth and (here not so) fast-flowing stream. ${ }^{36}$ Conversely, there is little wistfulness in Glenn Gould's brisk and percussive take on the F minor Prelude (an approach decried as 'egotism' by some) ${ }^{37}$ But instead of simply concluding that different performers, conductors or choreographers do different and more or less appropriate things to an inert musical object, my point is rather that the scores of the Prelude and the aria themselves inscribe the memory of and potential for bodily action. As a possible answer to John Butt's question of whether 'the music of Schütz and Bach tells us

${ }^{35}$ Nicholas Cook, Beyond the Score: Music as Performance (New York: Oxford University Press, 2014), 1. Cook's subsequent discussion centres predominantly on performance analysis and the production of meaning through performance style. Aspects of bodily gesture, meanwhile, are treated primarily as visual phenomena (especially 289-299).

${ }^{36}$ Johann Sebastian Bach, St. John Passion, CD recording, directed by John Eliot Gardiner, ARCHIV Produktion 02894193242 6, 1986.

${ }^{37}$ Johann Sebastian Bach, The Well-Tempered Clavier, Book II, CD recording, Glenn Gould, The Glenn Gould Edition, Sony Classics B01MQ22QMB, 1994. For the commentary (in a review of Edwin Fischer's recording of the set), see 'The Gramophone Choice', $<$ http://www.gramophone.co.uk/editorial/bachs-well-tempered-clavier $>$ (accessed 17 June 2019). 
anything about historical conceptions of emotion which goes beyond what we might glean from contemporary writings', I would venture this proposition of bodiliness as an intrinsic feature of their music's expressiveness, rather than a mere side effect arising from the necessity of reproducing works in performance. ${ }^{38}$ In the case of the F-minor Prelude, this starts in the opening bar with the keyboardist's hands and upper body leaning in to that opening semitone descent, in order to generate a sense of heaviness and affective timing that can engender the expressive effects noted by Levinson. In the aria, meanwhile, this potential for expressive activation of the notated text ranges from, say, the instrumentalists' fingers and bows rushing through the melismatic contortions of the ritornello material, to the intimation of panicked hyperventilation in the closely spaced semiquaver rests (for example, bars 3-4 and 32-33). Notation, in such a reading, becomes legible as a repository of particular ways of inhabiting or using the body: from states of tangible physical unease to the delightful 'sense of comfort' noted by Elisabeth Le Guin in Boccherini's string writing, to seemingly disembodied elation. ${ }^{39}$ Latent within the script, these modes of being-in-the-body are activated by performers each time the notation is realized anew in sound.

For sure, many of the figurations in Bach's gigue-aria rely on standard turns of phrase that appear in much less frenzied guises elsewhere, thus flagging up the danger of reverting to an essentializing approach to the expressive properties of a given musical formulation, this time under the banner of embodiment. The third movement of Benedetto Marcello's Oboe Concerto in D minor, for instance, which Bach incidentally transcribed for keyboard as part

\footnotetext{
${ }^{38}$ John Butt, 'Emotion in the German Lutheran Baroque and the Development of Subjective Time Consciousness', Music Analysis 29/1-3 (2010), 19.

${ }^{39}$ Elisabeth Le Guin, Boccherini's Body: An Essay in Carnal Musicology (Berkeley: University of California Press, 2006), 9.
} 
of his Italian concerto exercises in the 1710 s, makes use of the same sequential motive as seen in bars 5-8 of Bach's aria (Figure 4). ${ }^{40}$ Notwithstanding the shared motivic contours, however, it is the differences between Marcello's model and Bach's twisted replica that reveal how these series of notes can inscribe distinct modes of physical engagement. In Marcello, the sequence appears, so to speak, 'as it should' (bars 5-12): its repetitions neatly fall in line with the triple-metre pulse, as motivic emphasis and metric downbeat unfailingly coincide, thereby guiding the recurring bodily actions of the performers to generate a 'natural' sense of groundedness and flow. Bach's version, on the other hand, is intensely disturbing on a visceral level: the shifting downbeats and down-bows of the first violin part persistently work against the grain of the tactus; the inner voices provide what appears to be metrically regular support from bar 5, but with the downbeat missing each time; and the equally displaced motivic imitations in the bass (another feature reworked from Marcello) further confound any possibility of a stable, foot-tapping beat. Note, too, the ambiguity in metric conception between $6 / 8$ and $3 / 8$, evident in the correction of the initial time signature and inconsistent placement of bar lines. The disruptive energy of this opening ritornello is thus not merely a matter of playing with rhythm, metre and hypermetre as structural elements, but of inducing a group of musicians to engage in apparently uncoordinated, counterintuitive corporeal efforts to generate an uncomfortably out-of-sync experience. And once the solo voice enters in bar 17 , the notation prompts a bodily action set up for failure: the singer's incomplete echo of the instrumental acrobatics (note the missing semiquaver in bar 19) shows the vocalist incapable of replicating the challenging violin line from his throat - a strategy that, as Butt has explored in a related context, amounts to a musical indictment of

${ }^{40}$ My thanks to Werner Breig for drawing my attention to this piece. 
humanity's physiological (and, by extension, spiritual) imperfections in a postlapsarian world. $^{41}$

\section{$<<$ PLACE FIGURE 4 NEAR HERE $>>$}

It is this space of real or implied physicality afforded by the score that a performer inhabits when turning the dots on the page into a cogent sequence of sounds that impress themselves meaningfully on a listener's senses. In the video of Sellars' production, Gerhaher may or may not be feeling the emotions he is expressing (though most eighteenth-century theorists would have insisted that he should), but he produces and conveys them through comprehensive bodily engagement. ${ }^{42}$ This is less a matter of vigorous gesticulation, of which there is very little, and more down to his affective comportment and facial demeanour - his eyes staring, his head turning wildly from one side to the other, now imploring a segment of the audience, now shouting at the members of the chorus; in other words, a fully embodied vocalisation of Bach's soundless script. One larger question posed by his performance, then, is what a philosophy of musical expression might look like if it took more seriously the proposition that any piece of music is necessarily 'supersaturated' with the performance

${ }^{41}$ John Butt, Bach's Dialogue with Modernity: Perspectives on the Passions (Cambridge: Cambridge University Press, 2010), 79-80.

${ }^{42}$ See for example Carl Philipp Emanuel Bach's advice in his Versuch über die wahre Art das Clavier zu spielen (Berlin: Henning, 1753), 122: 'Indem ein Musickus nicht anders rühren kan, er sey dann selbst gerührt'. But see Susanne Langer's classic rejection of this model in Philosophy in a New Key: A Study in the Symbolism of Reason, Rite, and Art, third edition (Cambridge, Mass.: Harvard University Press, 1957), 211-224. 
event. ${ }^{43}$ Although I might not go as far as Daniel Leech-Wilkinson's claim that musical works exist solely in performance, since the histories and material traces of such performances tend to coalesce into ostensibly coherent shapes (or 'works') that subsist apart from individual performed instances, these shapes need to be recognized as the fragile and easily transformed entities that they are. ${ }^{44}$ For any sense of what a musical work might be arguably arises principally from its specific oral (and, more recently, recorded) history, made up of layers of remembered and forgotten performances that collectively determine its sonic identity. Gerhaher's enactment of 'Eilt, ihr angefochtnen Seelen' seems salutary, therefore, in insisting on a mode of full-blown corporeal engagement, more familiar from operatic singing, that collapses the myth of 'the music' existing out there in a bodiless sphere. The awareness of this process of real-time embodiment has no doubt receded in the age of mechanical and digital reproduction; Gerhaher's body is patently not present in the flesh when viewing a DVD recording, and even less so when listening to a sound-only version. ${ }^{45}$ But, as Deniz Peters has argued with regard to electronic music, bodies remain omnipresent even in the seemingly most disembodied forms of musicking, appearing 'via extension in listening activated by bodily knowledge all listeners have acquired during a lifetime experience of

${ }^{43}$ Elin Diamond and Elizabeth Bronfen, review of Carolyn Abbate, In Search of Opera, Cambridge Opera Journal 17/2 (2005), 215.

${ }^{44}$ Daniel Leech-Wilkinson, The Changing Sound of Music: Approaches to Studying Recorded Musical Performances (London: CHARM, 2009), chapter 2.1, paragraph 20, $<$ http://www.charm.rhul.ac.uk/studies/chapters/chap2.html> (accessed 17 June 2019). ${ }^{45}$ See Roger Parker, 'Giuseppe Verdi’s Don Carlo(s): “live” on DVD', The Opera Quarterly 26/4 (2010), 603-613, for a thoughtful exploration of the issues surrounding 'live on DVD' recordings. 
everyday touch-sound relationships. ${ }^{46}$ This capacity for 'feeling-in' was already intuited by Mattheson's contemporary Jean-Jacques Rousseau, who remarked that 'as soon as vocal signs strike your ear, they proclaim a being similar to yourself ... birds whistle, man alone sings, and one cannot hear either a song or an instrumental piece without immediately saying to oneself: another sensitive being is present. ${ }^{47}$ In this sense, any encounter with musical expressivity necessarily involves engaging with human corporeality in its multiple manifestations.

\section{VANISHING ACTS: BODIES CONCEALED AND EXPOSED}

So far, I have argued that performer's bodies constitute indispensable agents in instantiating any expressive potential enfolded in a musical score, even those by that presumed master of the abstract contrapuntal arts, J. S. Bach. Perhaps, though, if my argument concerns embodiment and presence - the here and now of Gerhaher's limbs, face and vocal cords animating Bach's text - a turn to eighteenth-century precedent is not required in order to grasp this music's expressive potential. We may content ourselves, in the vein of Gabrielsson's 1996 study and many after it, with measuring different speeds, dynamics and articulations in individual performances, and mapping these features onto any perceived expressive qualities. And ultimately, it seems, the human bodies involved in generating the sonic output can safely drop away again in such a scenario: Juslin even proposes that

${ }^{46}$ Deniz Peters, 'Introduction', in Bodily Expression in Electronic Music, ed. Deniz Peters, Gerhard Eckel and Andreas Dorschel (New York: Routledge, 2012), 4.

${ }^{47}$ Jean-Jacques Rousseau, 'Essay on the Origin of Languages', in Rousseau on Philosophy, Morality and Religion, ed. Christopher Kelly (Lebanon, NH: University Press of New England, 2007), 139-140. 
computerized performance offers the most reliable approach 'if we wish to draw clear conclusions about cause and effect ... This is, in fact, the only way to evaluate objectively the causal effect of individual features. ${ }^{48}$ Yet, as Matthew Head has recently admonished us, in aiming to understand performance as human action we need to steer clear not only of 'mystification, in which performance is beyond signification and conceptualisation', but also 'the "wrong" kind of concreteness that treats performances as things to measure. ${ }^{49}$ Moreover, my suggestion that particular kinds of physical engagement ended up inscribed in composed sound structures is in fact quite precisely historically locatable, centring, I would argue, on the invention of new emotionally charged musical styles and subjectivities in the decades around 1600. Even if the consolidation of some of these affective features (sighs, exclamations, laments, the 'Ohimè' of Monteverdi's Orfeo) could eventually give rise to the so-called 'contour theory' of musical expression, their historical specificity complicates the tacit assumption of the score-based nature and trans-historical validity of such expressive markers. ${ }^{50}$

When late sixteenth-century musicians and theorists gradually shifted their preoccupation from music's place within a harmonious universe to its potential to move the human affections, it was in the role of the performing subject that much of this expressive capacity was initially located. In 1602, one of the pioneers of the new approach, Giulio Caccini, asserted that the foundation of musical expressivity lay not solely in the imitation of

48 Juslin, Musical Emotions Explained, 140.

${ }^{49}$ Matthew Head, 'The Growing Pains of Eighteenth-Century Studies', Cambridge Opera Journal 27/2 (2015), 185.

${ }^{50}$ For a classic formulation of the contour theory, see Peter Kivy, Sound Sentiment: An Essay on the Musical Emotions (Philadelphia: Temple University Press, 1989). 
a poet's words through 'affective music', but in 'expressing them through affective singing', achieved through the judicious application of crescendos, decrescendos, exclamations and other vocal devices. ${ }^{51}$ Even if Caccini as composer took pains to notate many of these devices in order to enable an effective delivery of the underlying text, it was the skilled performer who released their expressive charge. A contemporary sonnet praising the soprano Virginia Ramponi Andreini in her performance of the title role of Monteverdi's opera Arianna in 1608 offers a glimpse of the extraordinary effects of this singing style:

Co' la bocca di rose, d'onde uscia

Il nettare che inebria alma e 'l senso,

Mentre disacerbava il duolo intenso

Arianna gentile i cor rapia.

Ma mentre accompagnava l'armonia,

La man stringendo al sen, co' affetto immense,

Spremeva l'alme e, se ben dritto io penso,

Gli angioli istessi a un tempo anche ferìa.

[While gentle Arianna assuaged our intense pain, she stole our hearts with a mouth of roses, from which poured forth the nectar that inebriates soul and sense. While accompanied by harmony, her hand pressed against her heart with intense affect,

${ }^{51}$ Giulio Caccini, Le Nuove Musiche (Florence: Marescotti, 1602), 'Ai Lettori'. 
squeezing our souls, and at that point, if I am right in thinking it, the angels themselves were wounded as well. $]^{52}$

Note that 'the music' is hardly thematized at all in this poetic outpouring; as 'accompanying harmony' it merely figures as the vehicle for a mode of intensely haptic communication, in which the singer's voice, mouth and hands connect palpably with both her listeners' souls and those survivors of the old universal harmony, the angels. Other contemporary writers similarly attested to the primacy of the performer in ensuring that listeners' affections were moved; if presented in an impassive or overly stylized manner, any musical utterance would, according to Michael Praetorius, 'affect and delight the audience very little, instead leaving them tired and bored' ${ }^{53}$

By the time Marcello and Bach were writing their sequences a century or so later, the seconda pratica-inspired sedimentation of physical into musical gesture was well advanced, and much of the expressive potential formerly ascribed to the corporeal presence of performance was transferred instead to compositional structure. In his 1757 translation of Pier Francesco Tosi's 1723 singing treatise, Johann Friedrich Agricola mused that 'the various rising and falling movements of the voice are determined by the composer in the notes; hence the singer cannot willingly do anything but express the affect through the

\footnotetext{
${ }^{52}$ Quoted in Emily Wilbourne, Seventeenth-Century Opera and the Sound of the Commedia dell'Arte (Chicago: University of Chicago Press, 2016), 56. Translation adapted from there. 53 'Welche böse Art dann ... die Auditores ... wenig afficiret unnd erlustiget / ja vielmehr verdrossen unnd schläfferig machet', Michael Praetorius, Syntagma Musicum, volume 3 (Wolfenbüttel: Holwein, 1619), 230.
} 
different sounds of his voice. ${ }^{54}$ In Jean-Philippe Rameau's seminal writings, too, harmony and dissonance became enshrined as the primary carriers of affective gesture, with wellprepared minor dissonances producing sweetness and tenderness, while violent and despairing passions demanded unprepared discords. ${ }^{55}$ Coupled with Mattheson's glossaries of genre, style and key characteristics, such accounts provided the foundation for locating expressivity more exclusively in the music's structural features, with the sounding realization in performance reduced to an afterthought. And yet the performing body remained imprinted in those structures, as brought out in Naomi Cumming's searching analysis of the aria 'Erbarme Dich’ from Bach's Passion according to St Matthew. Cumming highlights the 'physiological motivation for hearing semantic content in melodic units, in such a way as to yield an affective connotation', taking careful account of the ways in which the embodied quality of the contrapuntal lines is paramount to the piece's legendary expressive intensity. ${ }^{56}$ These melodic units, Cumming asserts, need to be 'performed with an emphasis that creates an association with familiar proprioceptive actions' in order to achieve their expressive

54 'Da aber die so mannigfaltigen Erhebungen und Erniedrigungen der Stimme, durch die Noten von dem Componisten schon vorgeschrieben sind; und dem Sänger also nichts willkührliches weiter übrig bleibt, als den Affect durch den verschiedenen Laut seiner Stimme auszudrücken'. Pier Francesco Tosi, Anleitung zur Singkunst, ed. and trans. Johann Friedrich Agricola (Berlin: Winter, 1757; facsimile edition, Wiesbaden: Breitkopf \& Härtel, 1994), 139.

${ }^{55}$ Jean-Philippe Rameau, Treatise on Harmony, trans. Philip Gossett (New York: Dover, 1971), 155.

${ }^{56}$ Cumming, "The Subjectivities of "Erbarme Dich"', 8. 
effect, an effect too complex to be easily assigned to a clear-cut category such as ' $g r i e f$ '. ${ }^{57}$ And indeed, a brief glance at the matrix of dots and dashes that make up the autograph of the work - the only trace we have of its initial existence - will reveal that any imagined musical 'lines' here can only become legible as affective gestures if envoiced as such, with the score mainly serving as a prompt sheet that affords a certain range of expressive realizations (Figure 5).$^{58}$ The notion of 'line' itself is of course a metaphor, too, aiming once more to capture the elusive process of experiencing and making sense of sequences of musical sound. Looking at the autograph instead of a modern transcription therefore not only reminds us of the initial physical act of inscription, but also casts productive doubt on our easy familiarity with those legible, seemingly self-evident melodic lines and arches in a cleanly printed modern edition, which effectively disguise the agency of a performer in actualizing any sense of musical phrase, direction or intention.

\section{$<<$ PLACE FIGURE 5 NEAR HERE $>>$}

An eighteenth-century performer hoping to learn how to fashion such expressive lines out of collections of notes on the page might have looked, for instance, to Johann Joachim Quantz's 1752 treatise on flute playing, which offers in-depth tuition on turning physical input into expressive output: 'A proportional opening of the teeth and mouth, and expansion of the throat, produce a thick, round and masculine tone quality. The forward and backward

${ }^{57}$ Cumming, 'The Subjectivities of "Erbarme Dich", 9-10, 22.

${ }^{58}$ See Nicholas Cook's comments on scores as scripts that 'choreograph a series of real-time, social interactions between players'. Nicholas Cook, 'Music as Performance', in The Cultural Study of Music: A Critical Introduction, ed. Martin Clayton (New York: Routledge, 2003), 206. 
motion of the lips makes the tone poised and pleasant. ${ }^{59}$ The main agent of expressivity for Quantz is the tongue, which 'is indispensable for musical enunciation and serves the same purpose as the bow-stroke upon the violin. ... For it must animate the expression of the passions in all respects, whether they be grand or sad, gay or pleasant or whatever else. ${ }^{60}$ Particular tongue movements, positions of the jaw and levels of attack are specified for different genres and styles, thus establishing a regime for the perfectly disciplined body producing the intended expressive outcome. As in Caccini's case, therefore, the performer's bodily input remains central for Quantz; but like Mattheson's style categories, Quantz's instructions are primarily aimed at exercising control, ensuring that the required effect is achieved without overstepping the proprieties of moderately affective behaviour: 'You must guard against all grimaces and, as much as possible, try to preserve in yourself a constant

59 'Eine proportionirliche Oeffnung der Zähne und des Mundes, und Ausdehnung der Kehle, verursachen einen dicken, runden, und männlichen Ton. Das Hin- und wiederziehen der Lippen machet den Ton zugleich schwebend und annehmlich.' Johann Joachim Quantz, Versuch einer Anweisung die Flöte traversiere zu spielen (Berlin: Voß, 1752), 51. Translation adapted from Johann Joachim Quantz, On Playing the Flute, trans. Edward R. Reilly (London: Faber, 2001), 59. 60 'Die Zunge ... ist zur musikalischen Aussprache höchst nöthig; und verrichtet eben das, was der Bogenstrich bey der Violine thut. ... Denn diese muß den Ausdruck der Leidenschaften, in allen Stücken, er mag prächtig oder traurig, lustig oder annehmlich, oder wie er sonst wolle, seyn, beleben.' Quantz, Versuch einer Anweisung, 61. Translation adapted from Quantz, On Playing the Flute, 79. 
composure. ${ }^{91}$ For a woodwind player, this ideally constituted body entailed a 'perfectly healthy physique; strong and open lungs; a long breath; even teeth that are neither too long nor too short; lips that are thin, smooth and delicate rather than puffed out and thick, with neither too much nor too little flesh, and which can close the mouth effortlessly; a fluent and agile tongue; well-formed fingers that are neither too short nor too long, too corpulent or too pointed, but equipped with strong nerves; and an unobstructed nasal passage for inhaling and exhaling with ease'. ${ }^{62}$ Such a constitution allowed for that 'singing of the soul' which for Quantz lay at the heart of expressive musical execution.

Here, then, might be another (partially negative) lesson from the eighteenth century, regarding the need to recognize the centrality of the performing body in generating musical expressivity, but also the growing suspicion with which overly physical approaches to music making were met, leading to performers' bodies increasingly disappearing behind the sounds or structures of the music: the 'performer as vessel' paradigm observed in the making. The

61 'Vor allen Grimassen muß man sich hüten, und sich soviel als möglich ist in einer beständigen Gelassenheit zu erhalten suchen.' Quantz, Versuch einer Anweisung, 106. Translation in Quantz, On Playing the Flute, 203.

62 'Einen vollkommen gesunden Körper; eine offene starke Brust; einen langen Athem; gleiche Zähne, die weder zu lang noch zu kurz sind; nicht aufgeworfene und dicke, sondern dünne, glatte und feine Lippen, die weder zu viel noch zu wenig Fleisch haben, und den Mund ohne Zwang zuschließen können; eine geläufige und geschikte Zunge; wohlgestallte Finger, die weder zu lang, noch zu kurz, noch zu dickfleischig, noch zu spitzig, sondern die mit starken Nerven versehen sind; und eine offene Nase, um den Athem sowohl leicht zu schöpfen, als von sich zu geben.' Quantz, Versuch einer Anweisung, 4. Translation adapted from Quantz, On Playing the Flute, 13. 
fact that many of these disciplining mechanisms remain in place in Western classical concert culture today, with its rows of neatly dressed and largely immobile musicians and spectators, may well account for the discomfort that Sellars' stagings of Bach's Passions have caused some critics. ${ }^{63}$ If certain aspects of eighteenth-century performance practice and pedagogy had the effect of dissociating pieces of music from bodily matters, Sellars instead placed the performers' corporeality at the heart of his conception - most notoriously perhaps in the prolonged kiss between Jesus and Judas in his Passion according to St Matthew of 2012, but throughout his stagings of both Passions in the musicians' unwavering commitment to exhausting the full force of their bodily resources in delivering their parts. Sellars thereby seems to have invited his performers to leap back past certain familiar regimes of restraint to an earlier, more visibly embodied 'simulation of affective extremes'; ${ }^{94}$ of the sort, perhaps, indicated in the preface to Emilio de' Cavalieri's path-breaking oratorio Rappresentatione di

${ }^{63}$ Rupert Christiansen declared Sellars' staging of Bach's Passion according to St Matthew a 'tasteless spectacle best appreciated with eyes closed'. See his review in The Daily Telegraph, 7 September 2014, $<$ http://www.telegraph.co.uk/culture/music/proms/11079980/BBC-Prom-66-St-MatthewPassion-review-verging-on-ludicrous.html> (accessed 17 June 2019).

${ }^{64}$ Susan McClary, 'Introduction: On Bodies, Affects and Cultural Identities in the Seventeenth Century', in Structures of Feeling in Seventeenth-Century Cultural Expression, ed. Susan McClary (Toronto: University of Toronto Press, 2013), 3-4. Of course, this 'simulation' was equally governed by detailed sets of rules concerning postures, gestures and facial expressions in stage acting. See Olga Termini, 'The Role of Diction and Gesture in Italian Baroque Opera', Performance Practice Review 6/2 (1993): Article 7 $<$ https://scholarship.claremont.edu/ppr/vol6/iss2/7 $>$. 
Anima, e di Corpo (1600), where singers are urged to 'express the words well, so they may be understood, and accompany them with gestures and movements, not only of the hands but other gestures that are efficacious aids in moving the affections'. ${ }^{65}$ Though firmly rooted in twenty-first-century artistic practice, Sellars' flagrantly inauthentic feat of putting Bach's liturgically conceived pieces on stage can thus appear surprisingly 'historically informed', albeit reaching for the time of Caccini and Andreini rather than Quantz and Marcello.

\section{TOWARDS CORPOREAL-HISTORICAL ATTUNEMENT}

If we embrace the proposition that musical expressivity springs from the exertions of historically conditioned performing bodies, we must also grapple with the historical situatedness of the performance events themselves. For once, in a routine liturgical setting, most of Bach's listeners did not get to see his performers at all, hidden away on the balconies of the Thomaskirche, thereby generating a distinctive kind of relationship between the performers' and congregants' bodily presence. Numerous further factors shaped the specific affective field within which Bach's Passions operated, including not only different tuning systems, the theory of the humours, the practice of communal hymn singing, and noisy commotion during church services, but also the assumption of a direct link between musical expression and the individual believer's soul. The Platonic fear of music's power to corrupt as well as delight, corroborated by the central tenets of Galenic medicine that connected

65 'Che esprima bene le parole, che siano intese, \& le accompagni con gesti, \& motiui non solamente di mani, ma di passi ancora, che sono aiuti molto efficaci à muouere l'affeto'. Emilio de' Cavalieri, Rappresentatione di Anima, e di Corpo (Rome: Mutij, 1600), 'A' Lettori', fol. 2r. Translation in Carol MacClintock, Readings in the History of Music in Performance (Bloomington: Indiana University Press, 1979), 183. 
physiological functions directly to moral outcomes, continued to shape attitudes to musical expressivity for much of the eighteenth century. A 1743 anatomical treatise, for instance, confirmed that all affects had immediate moral implications: 'Affect or "GemüthsBewegung" means when the soul fiercely desires or abhors something, in that it appears to it either good or evil ... and when through this fierce desire or disgust the body is transformed at the same time. ${ }^{66}$ In light of Mattheson's definition of an aria as a 'große Gemüthsbewegung', it becomes clear, therefore, that performing and listening to music in an appropriate manner was not merely an issue of social etiquette, but ultimately a matter of life and death, of salvation or damnation. According to the Göttingen theologian Joachim Meyer (a notorious detractor of Mattheson), hearing church cantatas in the wrong way - not understanding the words and listening only for pleasure instead of fostering the required feelings of devotion - put congregants at risk of mortal $\sin .{ }^{67}$

A historically nuanced reconstruction of this nexus between music and morality would likely come to somewhat different conclusions from a more philosophically-minded inquiry, such as Kivy's investigation of 'whether the music of such great composers as Bach, Mozart or Chopin is a "moral force" for the good. ${ }^{68}$ For Kivy, it is the "feeling of mind-

66 'Affectus: Gemüths=Bewegung heißt, wenn die Seele etwas hefftig verlanget oder nicht, indem es ihr gut oder böß vorkommt, und bey diesen hefftigen Verlangen oder Abscheu (welches also aus Uebereilung geschicht) der Cörper zugleich alteriret wird.' Otto Just Wreden, Kurzer u. deutlicher Unterricht von denen Theilen des Menschlichen Körpers (Hannover: Förster, 1737), 263.

${ }^{67}$ Joachim Meyer, Der anmaßliche Hamburgische Criticus Sine Crisi (Lemgo, 1728), 122.

${ }^{68}$ Peter Kivy, Antithetical Arts: On the Ancient Quarrel Between Literature and Music

(Oxford: Oxford University Press, 2009), 218. 
expanding exaltation' imparted by the beauty of great art that constitutes this music's character-building power. Kivy is happy to leave the donkeywork of determining what this greatness consists in to 'the music theorist, the musicologist, and all others engaged in the analysis and the criticism of the absolute music canon' ${ }^{69}$ However, when he announces elsewhere that 'Georg Philipp Telemann wrote yards and yards of mournful music, but it would be bizarre to describe very much of it as "moving", Kivy appears reluctant to contemplate the very different moral and affective sensibilities that - as a historical musicologist may point out - shaped the production and reception of both Telemann's and Bach's music. ${ }^{70}$ Johann Adolph Scheibe, for instance, summarized his ideal of musical expressivity as an invention which 'causes in its listeners a motion' that 'takes hold of the heart, bewitches the senses, freezes the blood and finally, upon recovery, induces wonder, thereupon reflection and ultimately a quiet sense of awe towards the infinite and eternal love of the Creator'. ${ }^{11}$ 'Mind-expanding' indeed, one might say; but the piece which Scheibe chose to exemplify this process was by none other than Telemann, specifically the aria 'Ach

${ }^{69}$ Kivy, Antithetical Arts, 231.

${ }^{70}$ Peter Kivy, Music Alone: Philosophical Reflections on the Purely Musical Experience (Ithaca, 1991), 162.

71 'Wenn hingegen ein vernünftiger, ein feuriger Componist... eine so nachdrückliche Erfindung zeiget, daß sie die Zuhörer auf das empfindlichste rühret, daß sie bey ihnen eine Bewegung verursachet, welche das Herz einnimmt, die Sinne bezaubert, das Geblüte erstarren macht, und wodurch endlich bey der Erholung eine Bewunderung, hieraus eine Ueberlegung, und endlich eine stille Ehrfurcht gegen die unendliche und ewige Liebe des Schöpfers entsteht: so ist solches ein unumstößlicher Beweis des erhabenen Geistes des Verfassers.' Scheibe, Der Critische Musikus, 85. 
sehet, welch ein Mensch' from his 1737 Passion according to St John TwV5:22, which marks the 'Ecce homo' climax of the Passion narrative (Figure 6).

\section{$<<$ PLACE FIGURE 6 NEAR HERE $>>$}

Scheibe's choice can certainly seem odd. The (anonymous) text is all body, offering the kind of gory detail that might indeed 'freeze the blood' of those contemplating the dreadful sight:

Ach sehet! welch ein Mensch ist das!

Sein Rücken ist voll blutger Striemen,

Der starren Dornen spitzge Pfriemen

Durchbohren die zerfleischte Stirne

Und dringen ihm bis ans Gehirne.

Ach sehet! welch ein Mensch ist das!

Die Hand erstarrt vor harten Seilen,

Sein heilges Haupt ist voller Beulen,

Sein Leib von Blut und Eiter nass.

Ach sehet! welch ein Mensch ist das!

Ach Gottes ein'ger Sohn ist das.

[Behold, what a man is this! His back is covered in bloody weals, the spiky points of rigid thorns pierce the lacerated forehead and penetrate into his brain. His hand grown stiff from the coarse ropes, his blessed head is covered in bruises, his body wet with blood and pus. Behold, what a man is this! It is God's own son.] 
Telemann's setting, meanwhile, seems to eschew a performative equivalent of the libretto's excesses, instead presenting a strikingly plain musical fabric designed to bring about its intended effect of 'Traurig' through a drastic reduction of expressive devices. Wolfgang Hirschmann has described the piece as a 'quiet sinking into a serious, compassionate sadness', achieved through a lack of polyphonic, melismatic or virtuosic elaboration, instead concentrating on the voice's declamatory intensity. ${ }^{72}$ The monochrome texture, unchanging rhythms and repeated notes in the string accompaniment call for a smooth and uniform style of delivery devoid of demonstrative physical gestures, while the 'downward exertion' of the opening vocal motive, later amplified to cover the uncomfortable span of a diminished 7 th (bars 9-10), may lend a drooping passivity to the singer's pronouncements. ${ }^{73}$ Producing an 'inward climax' at this crucial juncture in the Passion narrative, Telemann's aria seems to invite a distilled, internalized manner of expression from its performers, removed from the jarring physicality of the accompanying text - a Quantzian kind of bodily restraint, one might

${ }^{72}$ Wolfgang Hirschmann, “"Nachdruck” und “edle Simplizität” in Telemanns Kirchenmusik', in Telemann und die Kirchenmusik, ed. Carsten Lange and Brit Reipsch (Hildesheim: Olms, 2011), 34. In Hirschmann's analysis, these features add up to a compelling example of 'edle Einfalt' (noble simplicity), that guiding aesthetic category of eighteenth-century Empfindsamkeit invoked by Mattheson and later Johann Georg Sulzer, in which art reached its greatest emotional potential through a self-conscious artlessness.

${ }^{73}$ Cumming identifies this as an archetypal 'grief' gesture, following Manfred Clynes. Cumming, "The Subjectivities of "Erbarme Dich", 22. 
say, written into the musical fabric itself. ${ }^{74}$ When performed in this way, Telemann's music superimposes a mode of subdued contemplation onto the nakedly descriptive libretto, thereby steering his listeners in their emotive response beyond an initial reaction of shock towards a more emotionally collected appraisal of the spectacle unfolding in their mind's eye.

This double distancing effect - the performers' expressive stance dissociated from the immediacy of the poetry, and their listeners placed in the position of external witnesses to an internalized affective experience - is arguably enhanced further by the instruction in the surviving manuscript copy of the work that the aria be performed by 'all the voices and the oboes', as a kind of 'tutti aria'. The unusual scoring decision seemed so implausible to those preparing the one available modern edition of the work (1976) that they turned the movement instead into a four-part chorus by adding independent vocal parts for alto, tenor and bass. ${ }^{75}$ Certainly the suggested presentation of the melody by several voices and instruments, with the dispersed bodily and expressive agency this implies, seems to leave little room for the individual outpouring of expressive intensity once offered by Monteverdi's Arianna. Heinichen's commentary on the comparable phenomenon of the 'unison aria', in which a solo voice is amplified monophonically by the accompanying instruments, can perhaps offer a glimpse of the intended sound effect: 'They let the strings (very rarely the winds) play along with the voice in a pure piano at the unison or octave, which notably lightens the

\footnotetext{
${ }^{74}$ Hirschmann, 'Telemanns Kirchenmusik', 37. On this process of 'Verinnerlichung', see Laurenz Lütteken, Das Monologische als Denkform in der Musik zwischen 1760 und 1785 (Tübingen: Niemeyer, 1998), 29-33.

${ }^{75}$ Georg Philipp Telemann, Johannes-Passion, ed. Felix Schroeder (Zurich: Eulenburg, 1976). According to Hirschmann, the same instruction accompanies one further aria in the work, 'Es bleibet dabei' (No. 49); see Hirschmann, 'Telemanns Kirchenmusik', 32.
} 
dominant voice ... adds something to it and, to speak in physical terms, distributes it in such a way through the surrounding air that the voice is seemingly extended further towards the ear, and it no longer seems as if the string instruments were playing along, but as if the whole harmony arising from the general unison originated solely from the voice. Who has not observed in their own experience that these kinds of arias set by famous composers often achieve the greatest effect in public' ${ }^{76}$ Heinichen appears to be describing a kind of surround-sound avant la lettre here, detached from the material bodies producing it, and enabling a fantasy of an all-encompassing, incorporeal voice. Perhaps similarly, Telemann's aria, with its inward-looking stance as well as its non-specific, distributed sound source, offered a mode of vocality that appeared especially moving through its less bodily and more free-floating sonic quality. His aria thereby afforded a heightened experience of that 'disembodied emanation' which musical sound became in the modern Western imagination. ${ }^{77}$

${ }^{76}$ Sie laßen nehmlich die Saiten-Instrumenta (sehr selten die blasenden) mit der VocalStimme ein sauberes piano in unison, oder auch wohl all Ottava mitspielen, welches denn die dominierende, auff spirituelle Arth gesetzte Vocal Stimme besonders releviret ... ihr gleichsam einen Zusatz giebet, und das Wesen derselben, physice zu reden, dergestalt durch die umbliegende Lufft verstreuet, daß die Stimme dem Gehöre nach gleichsam weiter extendiret wird, und nicht mehr scheinet, als wenn die Saiten-Instrumenta mit spieleten, sondern als wenn alle durch den General-Unisonum enstehende Harmonie ... von der VocalStimme alleine herkäme. Wer aus der Erfahrung nicht observiret hat, daß dergleichen von berühmten Practicis gesetzte Arien in publico sehr offt den größten Effect thun...', Heinichen, Der General-Bass, 60.

${ }^{77}$ Linda Phyllis Austern, 'Introduction', in Music, Sensation and Sensuality, ed. Linda Phyllis Austern (New York: Routledge, 2002), 6. 
In this way, Telemann's piece could be heard not only as re-activating a pre-modern notion of Pythagorean cosmic harmony that transcends the bodily foundation of human music making, but also as a harbinger of things to come: anticipating a version of the ideal Kantian listener, engaged in disinterested contemplation of an aesthetic object. Conversely, though, and perhaps more profitably, one might regard the withdrawn expressive stance implied in Telemann's score as corporeally grounded to the same extent as a more overtly physical act of musicking: the aria remains an 'aggregate of fleshly phenomena', as Le Guin so evocatively put it. ${ }^{78}$ After all, Scheibe was unequivocal about the piece's very palpable bodily effects: blood freezing, senses bewitched, and so on. Even ostensibly disembodied practices of contemplation - such as Scheibe's sense of wonder and awe in which his listening experience culminated - thus emerged out of particular physiological conditions that remained crucial in determining the affective potency of musical practices seemingly untethered from the bodily realm. Still today, those ideal listeners attending Sellars' Passion performances, placed in a concert hall environment in which their own bodies engage in a perpetual feat of self-concealment, retain their corporeality as the indispensable basis from which experiences of musical expressivity are enabled and sustained. Rather than imposing an extraneous layer of physicality, then, Gerhaher's rendering of Bach's aria instead merely exposes certain aspects of this music's vital corporeal underpinnings, and in the process renegotiates the frictions between embracing or denying bodily agency in eighteenth-century musicking. Present-day performances such as these can thereby subtly - or radically transform our appreciation of eighteenth-century musical expressivity, by putting us in touch with less habitual modes of being-in-the-body as performers and listeners. Conversely, closer attunement to the historical dimension of the expressive practices of musicking bodies can

\footnotetext{
${ }^{78}$ Le Guin, Boccherini’s Body, 36.
} 
productively unsettle some of the certainties underlying current empirical or philosophical accounts of musical expression. By keeping hold of this tension between historical insights and present preoccupations, with one constantly inflecting the other, we might begin to account more profitably for the bewildering multiplicity of possible modes of being expressive in music. 